\title{
SISTEM PERAMALAN PENJUALAN PAVING BLOCK MENGGUNAKAN METODE SINGLE MOVING AVERAGE
}

\author{
Saefudin, ${ }^{1}$ Diki Susandi ${ }^{2}$, Fairuza Nafis ${ }^{3}$ \\ ${ }^{1}$ Program Studi Sistem Informasi Fakultas Teknologi Informasi Universitas Serang Raya \\ ${ }^{2,3}$ Program Studi Informatika Fakultas Teknologi Informasi Universitas Serang Raya \\ Jln. Raya Cilegon Serang - Drangong Kota Serang \\ ${ }^{1}$ saefudin12@gmail.com \\ 2 unsera.diky@gmail.com \\ ${ }^{3}$ fairuza.nafis.fn@gmail.com
}

\begin{abstract}
Abstrak - Teknologi informasi sudah menjadi kebutuhan dalam kehidupan masyarakat saat ini, karena sistem dan teknologi informasi dapat membantu dalam pengambilan keputusan yang efektif dan efisien. Saat ini Inti Jaya Block membutuhkan suatu sistem yang terkomputerisasi untuk membantu dalam mengambil keputusan, karena kendala yang sering terjadi yaitu masih kesulitan dalam menentukan jumlah produksi untuk periode mendatang. Tujuan dari penelitian ini adalah membuat sistem peramalan penjualan menggunakan metode single moving average. Metode single moving average ini digunakan untuk melakukan peramalaman dalam menentukan berapa jumlah produksi yang harus disediakan pada periode mendatang. Sistem Peramalan ini dibuat dengan menggunakan metode pengembangan sistem Waterfall Model, perancangan sistemnya menggunkaan UML dan bahasa pemrograman PHP dan database MySQL. Hasil peramalan yang telah dilakukan, didapat nilai kesalahan terkecil yang berbeda tiap periode pada setiap barang. Nilai kesalahan terkecil untuk Paving Block Tipe Bata menggunakan 6 periode, dengan nilai MAD sebesar 437,037, MSE sebesar 262708, dan MAPE sebesar 3,76935\% dan untuk tipe hexagon menggunakan 6 periode diperoleh nilai penjualan1980 dengan nilai MAD 125, MSE 24986,3 dan MAPE 6,32166\%.
\end{abstract}

Kata Kunci : Sistem Peramalan, Penjualan, Peramalan, Single Moving Average. Waterfall

\section{PENDAHULUAN}

Teknologi informasi sudah menjadi kebutuhan dalam kehidupan masyarakat saat ini, karena masyarakat saat ini cenderung sangat bergantung pada sesuatu yang digital.Sistem dan teknologi informasi juga membantu dalam pengambilan keputusan yang tepat berdasarkan informasi yang tersedia. Dengan adanya teknologi informasi saat ini, maka akan memudahkan untuk melakukan pengolahan data secara efektif dan efisien serta dapat menghasilkan suatu informasi yang dibutuhkan secaracepat dan akurat.

Dunia usaha yang tumbuh dan berkembang semakin cepat, mengakibatkan semakin ketatnya persaingan dalam dunia usaha, maka pihak perusahaan harus mampu menganalisis dan meramalkan berbagai kemungkinan yang akan terjadi di masa yang akan datang. Kegiatan meramalkan masa yang akan datang merupakan salah satu usaha perusahaan dalam pengambilan keputusan yang efektif dan efisien dalam kelangsungan usaha.

Inti Jaya Block merupakan Usaha Mikro Kecil Menengah (UMKM) yang bergerak di bidang manufaktur yaitu memproduksi dan menjual paving block, yang berlokasi di Jl. Kali Gandu, Cilegon, Banten. Adapun beberapa jenis paving block yang disediakan pada Inti Jaya Block yaitu paving block tipe bata dan paving block tipe hexagon. Pada proses kegiatan produksinya pihak perusahaan masih mengalami kesulitan dalam menentukan jumlah produksi, karena selama ini dalam menentukan jumlah produksi hanya dengan perkiraan saja, tanpa ada perhitungan yang baik untuk mengetahui bayangan apa yang akan terjadi di masa mendatang, oleh sebab itu maka sering terjadinya kekurangan jumlah persediaan produksi atau bahkan kelebihan jumlah produksi. Serta masalah lain pada Inti Jaya Block saat ini yaitu dalam pengolahan data belum menggunakan sistem yang terkomputerisasi. Data penjualan masih dikelola manual menggunakan pembukuan untuk bukti transaksi penjualan, sehingga akan menjadi masalah jika ada rekapan data history penjualan yang terlewat.Karena berdasarkan data penjualan periode yang lalu dapat diketahui dan diramalkan jumlah penjualanperiode mendatang untuk menentukan berapa jumlah produksi yang harus disediakan pada periode mendatang.

Peramalan tersebut dapat bekerja secara optimal jika didukung dengan sebuah metode. Metode yang digunakan dalam peramalan ini adalah dengan menggunakan metode SingleMoving Average yang merupakan suatu metode peramalan yang mengkombinasikan sejumlah data aktual 
periode sebelumnya untuk menghasilkan peramalan dimasa mendatang.

Tujuan dari penelitian ini adalah membuat suatu sistem peramalan penjualan paving block menggunakan metode Single Moving Average untuk meramalkan penjulan pada bulan selanjutnya sehingga Inti Jaya Block dapat menentukan jumlah produksi yang harus disediakan pada periode mendatang.

\section{METODOLOGI PENELITIAN}

Berikut ini adalah tahapan penelitian yang digunakan dalam membuat sistem peramalan penjualan.

a) Studi Literatur

Melakukan studi literatur yang ada kaitannya dengan yang akan digunakan dalam penelitian ini,seperti referensi dari buku, jurnal dan bacaan-bacaan yang masih terkait dengan penelitian. b) Identifikasi Masalah

Melakukan identifikasi tentang masalah apa yang akan dibahas yang berkaitan dengan peramalan penjualan, serta dalam pengambilan keputusan untuk menghasilkan peramalan penjualan dimasa mendatang.

c) Pengumpulan Data

Pengumpulan data dilakukan untuk mendapatkan informasi yang akan dibutuhkan dalam mencapai tujuan penelitian. Proses pengumpulan data ini dilakukan dengan metode wawancara dan observasi.

d) Pemilihan Metode

Metode yang digunakan dalam penelitian ini adalah Single Moving Average, yang merupakan suatu metode peramalan yang mengkombinasikan sejumlah data aktual periode sebelumnya untuk menghasilkan peramalan dimasa mendatang.

e) Pengembangan Sistem

Pengembangan perangkat lunak menggunakan metode waterfall, yang terdiri dari analisis, desain, pengkodean, pengujian..

f) Implementasi Sistem

Tahapan ini mengimplementasikan sistem peramalan penjualan yang sudah dirancang atau dibangun pada Inti Jaya Block.

g) Hasil

Pada tahap ini, hasil dari pembuatan sistem peramalan penjualan menggunakan metode Single Moving Average akan digunakan pada Inti Jaya Block sebagai pendukung keputusan dalam meramalkan penjualan di periode mendatang..

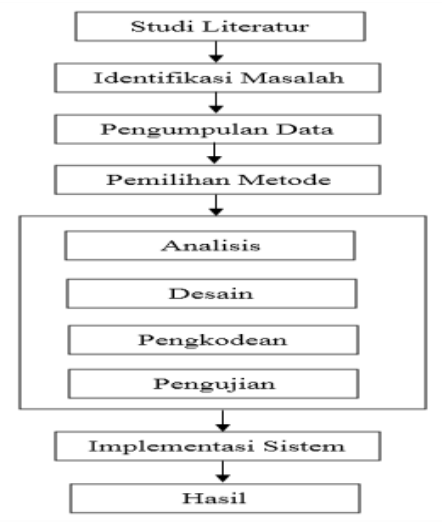

Gambar 2.1 Tahapan Penelitian

\section{PERANCANGAN SISTEM}

\subsection{Usecase Diagram}

Use case diagram yaitu pemodelan untuk menggambarkan interaksi antara sistem dan aktor. secara grafis untuk mengetahui fungsi apa saja yang ada didalam sebuah sistem dan siapa saja yang terlibat dalam menggunakan fungsi-fungsi tersebut.

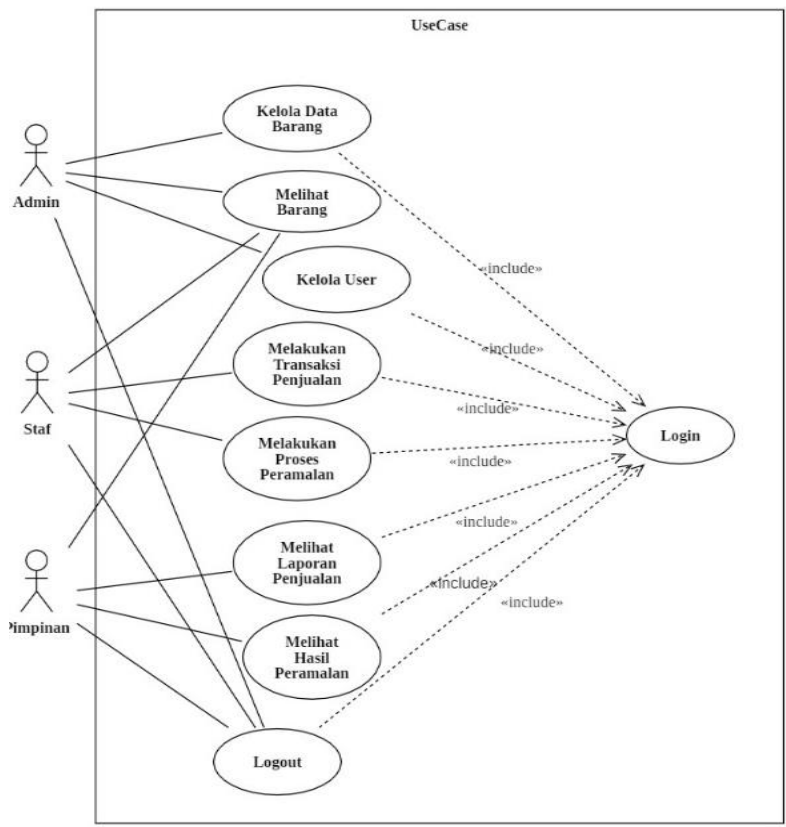

Gambar 3.1 Use Case Diagram

\subsection{Activity Diagram}

Diagram Activity ini digunakan untuk menggambarkan tahapan dari setiap proses yang terjadi.

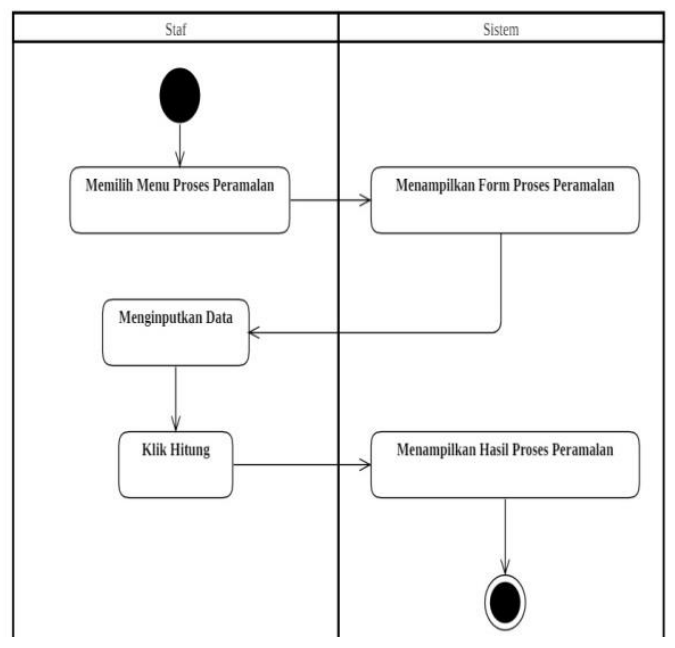




\section{Class Diagram}

\section{Gambar 3.2. Activity Diagram}

Class diagram digunakan untuk menampilkan kelas-kelas atau paket-paket di dalam sistem dan memberikan gambaran sistem secara statis dan relasi antar data. Berikut ini adalah class diagramyang diusulkan:

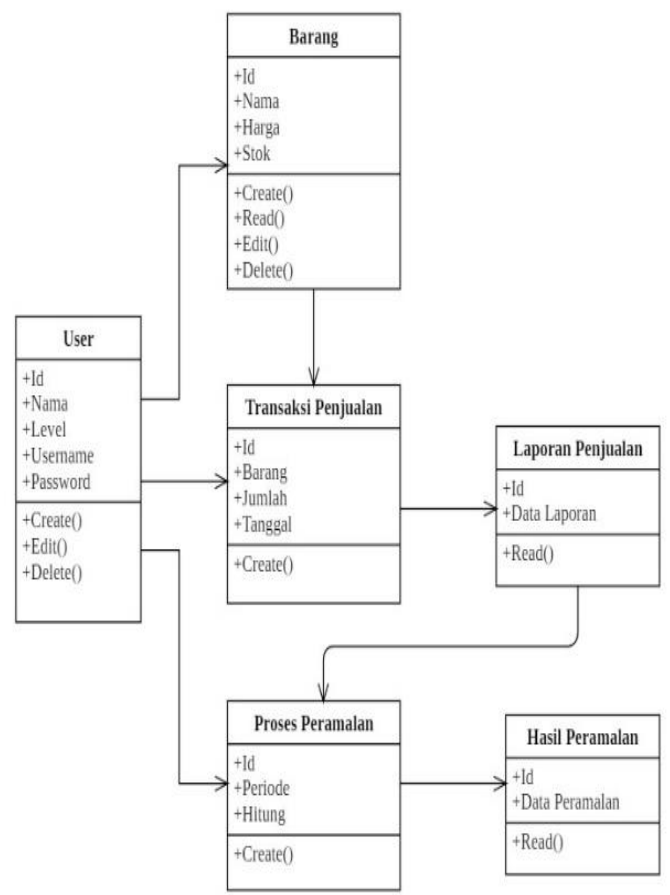

Gambar 3.3 Class Diagram

\section{HASIL DAN PEMBAHASAN}

\subsection{Perhitungan Metode Singel Avarage}

Untuk melakukan perhitungan metode singel average dibutuhkan data yang akan digunakan dalam menentukan peramalan penjualan Pavling Block. Ada dua Jenis Pavling Block, yaitu jenis bata dan hexagon. Berikut ini adalah data penjualan pavling block bulan April 2019 sampai dengan April 2021.

TABEL I.

DATAPENJULAN PAVLING BLOCK TIPE BATA

\begin{tabular}{|c|l|c|c|}
\hline No & Bulan & Tahun & $\begin{array}{c}\text { Penjualan } \\
(\text { At) }\end{array}$ \\
\hline 1 & April & 2019 & 11250 \\
\hline 2. & Mei & 2019 & 11550 \\
\hline 3. & Juni & 2019 & 10800 \\
\hline 4 & Juli & 2019 & 11850 \\
\hline 5 & Agustus & 2019 & 11000 \\
\hline
\end{tabular}

\begin{tabular}{|c|l|c|c|}
\hline No & Bulan & Tahun & $\begin{array}{c}\text { Penjualan } \\
(\text { At) }\end{array}$ \\
\hline 6 & September & 2019 & 11300 \\
\hline 7 & Oktober & 2019 & 11900 \\
\hline 8 & November & 2019 & 11550 \\
\hline 9 & Desember & 2019 & 11450 \\
\hline 10 & Januari & 2020 & 10650 \\
\hline 11 & Februari & 2020 & 11800 \\
\hline 12 & Maret & 2020 & 12100 \\
\hline 13 & April & 2020 & 10750 \\
\hline 14 & Mei & 2020 & 11750 \\
\hline 15 & Juni & 2020 & 10950 \\
\hline 16 & Juli & 2020 & 12000 \\
\hline 17 & Agustus & 2020 & 11650 \\
\hline 18 & September & 2020 & 11300 \\
\hline 19 & Oktober & 2020 & 12250 \\
\hline 20 & November & 2020 & 11950 \\
\hline 21 & Desember & 2020 & 11350 \\
\hline 22 & Januari & 2021 & 11800 \\
\hline 23 & Februari & 2021 & 11950 \\
\hline 24 & Maret & 2021 & 12400 \\
\hline & & & \\
\hline
\end{tabular}

TABEL II.

DATA PENJULAN PAVLING BLOCK TIPE HEXAGON

\begin{tabular}{|c|l|c|c|}
\hline No & Bulan & Tahun & $\begin{array}{c}\text { Penjualan } \\
(\mathbf{A t})\end{array}$ \\
\hline 1 & April & 2019 & 1944 \\
\hline 2. & Mei & 2019 & 1836 \\
\hline 3. & Juni & 2019 & 2025 \\
\hline 4 & Juli & 2019 & 1701 \\
\hline 5 & Agustus & 2019 & 1755 \\
\hline 6 & September & 2019 & 1701 \\
\hline 7 & Oktober & 2019 & 1998 \\
\hline 8 & November & 2019 & 2187 \\
\hline 9 & Desember & 2019 & 1755 \\
\hline 10 & Januari & 2020 & 1836 \\
\hline 11 & Februari & 2020 & 2133 \\
\hline 12 & Maret & 2020 & 2052 \\
\hline 13 & April & 2020 & 1701 \\
\hline 14 & Mei & 2020 & 1890 \\
\hline
\end{tabular}




\begin{tabular}{|c|c|c|c|}
\hline No & Bulan & Tahun & $\begin{array}{c}\text { Penjualan } \\
\text { (At) }\end{array}$ \\
\hline 15 & Juni & 2020 & 1809 \\
\hline 16 & Juli & 2020 & 1944 \\
\hline 17 & Agustus & 2020 & 2025 \\
\hline 18 & September & 2020 & 1836 \\
\hline 19 & Oktober & 2020 & 1836 \\
\hline 20 & November & 2020 & 1890 \\
\hline 21 & Desember & 2020 & 2025 \\
\hline 22 & Januari & 2021 & 2133 \\
\hline 23 & Februari & 2021 & 1917 \\
\hline 24 & Maret & 2021 & 2079 \\
\hline
\end{tabular}

Berdasarkan tabel 4.1, maka akan dilakukan proses perhitungan peramalan penjualan pavling block tipe bata metode singel avarege dengan menggunakan 6 skala periode. Berikut ini adalah proses perhitungannya.

1. Perhitungan Penjualan Pavling Block tipe Bata 6 periode

Peramalan Oktober 2019

$$
=\frac{(11250+11150+108006+11850+11000+11900)}{6}=11297,1
$$

Peramalan November 2019

$$
=\frac{(11550+108006+11850+11000+11300+11900)}{6}
$$

Peramalan Desember 2019

$$
=\frac{(108006+11850+11000+11300+11900+11550)}{6}=11400
$$

Peramalan Januari 2020

$$
=\frac{(11850+11000+11300+11900+11550+11450)}{6}=1508,3
$$

Peramalan Februari 2020

$$
=\frac{(11000+11300+11900+11550+11450+10650)}{6}=1308,3
$$

Peramalan Maret 2020

$$
=\frac{(11300+11900+11550+11450+10650+11800)}{6}=1441,7
$$

Peramalan April 2020

$$
=\frac{(11900+11550+11450+10650+11800+12100)}{6}=11575
$$

Peramalan Mei 2020

$$
=\frac{(11550+11450+10650+11800+12100+10750)}{6}=1383,3
$$

Peramalan Juni 2020

$$
=\frac{(11450+10650+11800+12100+10750+11750)}{6}=1416,7
$$

Peramalan Juli 2020

$$
=\frac{(10650+11800+12100+10750+11750+10950)}{6}=1333,3
$$

Peramalan Agustus 2020

$$
=\frac{(11800+12100+10750+11750+10950+12000)}{6}=11558,3
$$

Peramalan September 2020

$$
=\frac{(12100+10750+11750+10950+12000+11650)}{6}=1533,3
$$

Peramalan Oktober 2020

$=\frac{(10750+11750+10950+12000+11650+11300)}{6}=11400$

Peramalan November 2020

$$
=\frac{(11750+10950+12000+11650+11300+12250)}{6}=11650
$$

Peramalan Desember 2020

$$
=\frac{(10950+12000+11650+11300+12250+11950)}{6}=1683,3
$$

Peramalan Januari 2021

$$
=\frac{(12000+11650+11300+12250+11950+11350)}{6}=11750
$$

Peramalan Februari 2021

$$
=\frac{(11650+11300+12250+11950+11350+11800)}{6}=1716,7
$$

Peramalan Maret 2021

$$
=\frac{(11300+12250+11950+11350+11800+11950)}{6}=1766,7
$$

Peramalan April 2021

$$
=\frac{(12250+11950+11350+11800+11950+12400)}{6}=11950
$$

2. Tabel Hasil Perhitungan Penjualan Pavling Block

TABEL III.

HASIL PERHITUNGAN PERAMALAN PENJUALAN PAVLING BLOCK TIPE BATA METODE SINGLE MOVING AVERAGE

\begin{tabular}{|c|c|c|c|}
\hline Bulan & Tahun & $\begin{array}{c}\text { Penjualan } \\
(\mathbf{A t})\end{array}$ & $\begin{array}{c}\text { Peramalan } \\
(\mathbf{F t})\end{array}$ \\
\hline April & 2019 & 11250 & - \\
\hline Mei & 2019 & 11550 & - \\
\hline Juni & 2019 & 10800 & - \\
\hline Juli & 2019 & 11850 & - \\
\hline Agustus & 2019 & 11000 & - \\
\hline September & 2019 & 11300 & - \\
\hline
\end{tabular}




\begin{tabular}{|c|c|c|c|}
\hline Bulan & Tahun & $\begin{array}{c}\text { Penjualan } \\
(\mathbf{A t})\end{array}$ & $\begin{array}{c}\text { Peramalan } \\
(\mathbf{F t})\end{array}$ \\
\hline Oktober & 2019 & 11900 & 11291,7 \\
\hline November & 2019 & 11550 & 11400 \\
\hline Desember & 2019 & 11450 & 11400 \\
\hline Januari & 2020 & 10650 & 11508,3 \\
\hline Februari & 2020 & 11800 & 11308,3 \\
\hline Maret & 2020 & 12100 & 11441,7 \\
\hline April & 2020 & 10750 & 11575 \\
\hline Mei & 2020 & 11750 & 11383,3 \\
\hline Juni & 2020 & 10950 & 11416,7 \\
\hline Juli & 2020 & 12000 & 11333,3 \\
\hline Agustus & 2020 & 11650 & 11558,3 \\
\hline September & 2020 & 11300 & 11533,3 \\
\hline Oktober & 2020 & 12250 & 11400 \\
\hline November & 2020 & 11950 & 11650 \\
\hline Desember & 2020 & 11350 & 11683,3 \\
\hline Januari & 2021 & 11800 & 11750 \\
\hline Februari & 2021 & 11950 & 11716,7 \\
\hline Maret & 2021 & 12400 & 11766,7 \\
\hline April & 2021 & - & 11950 \\
\hline & & & \\
\hline
\end{tabular}

\begin{tabular}{|c|c|c|c|}
\hline Januari & 2020 & 1836 & 1849,5 \\
\hline Februari & 2020 & 2133 & 1872 \\
\hline Maret & 2020 & 2052 & 1935 \\
\hline April & 2020 & 1701 & 1993,5 \\
\hline Mei & 2020 & 1890 & 1944 \\
\hline Juni & 2020 & 1809 & 1894,5 \\
\hline Juli & 2020 & 1944 & 1903,5 \\
\hline Agustus & 2020 & 2025 & 1921,5 \\
\hline September & 2020 & 1836 & 1903,5 \\
\hline Oktober & 2020 & 1836 & 1867,5 \\
\hline November & 2020 & 1890 & 1890 \\
\hline Desember & 2020 & 2025 & 1890 \\
\hline Januari & 2021 & 2133 & 1926 \\
\hline Februari & 2021 & 1917 & 1957,5 \\
\hline Maret & 2021 & 2079 & 1939,5 \\
\hline April & 2021 & - & 1980 \\
\hline
\end{tabular}

TABEL IV.

HASIL PERAMALAN PENJUALAN PAVING BLOCK TIPE HEXAGON 6 PERIODE

\begin{tabular}{|c|c|c|c|}
\hline Bulan & Tahun & $\begin{array}{c}\text { Penjualan } \\
(\mathbf{A t})\end{array}$ & $\begin{array}{c}\text { Peramalan } \\
(\mathbf{F t})\end{array}$ \\
\hline April & 2019 & 1944 & - \\
\hline Mei & 2019 & 1836 & - \\
\hline Juni & 2019 & 2025 & - \\
\hline Juli & 2019 & 1701 & - \\
\hline Agustus & 2019 & 1755 & - \\
\hline September & 2019 & 1701 & - \\
\hline Oktober & 2019 & 1998 & 1827 \\
\hline November & 2019 & 2187 & 1836 \\
\hline Desember & 2019 & 1755 & 1894,5 \\
\hline
\end{tabular}

\section{Pengujian Hasil Peramalan}

Hasil dari perhitungan peramalan kemudian dilakukan pengujian akurasi menggunakan Mean Absolute Deviation (MAD), Mean Square Error (MSE), dan Mean Absolute Percentance Error (MAPE). Berikut ini hasil pengujiannya.

Pengujian paving block tipe bata menggunakan 6 periode di bulan April 2021 diperoleh nilai penjualan 11,950 dengan nilai MAD 437,037, MSE 262,708, dan MAPE 3,76935\%.

Pengujian paving block tipe hexagon menggunakan 6 periode di bulan April 2021 diperoleh nilai penjualan1980 dengan nilai MAD 125, MSE 24986,3 dan MAPE 6,32166\%.

\subsection{Tampilan Sistem Peramalan Penjualan \\ 1. Tampilan Login}




Gambar 4.1 Tampilan Login

\section{Tampilan Halaman User}

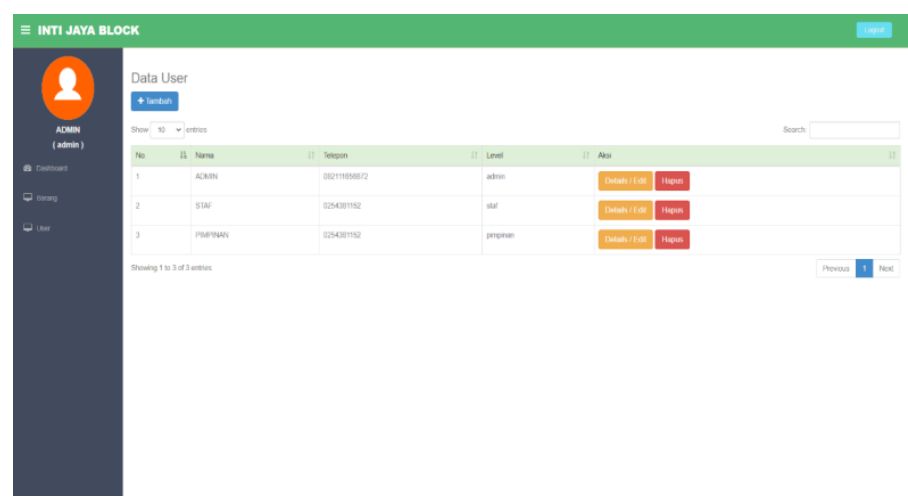

Gambar 4.2 Tampilan User

\section{Tampilan Halaman Utama}

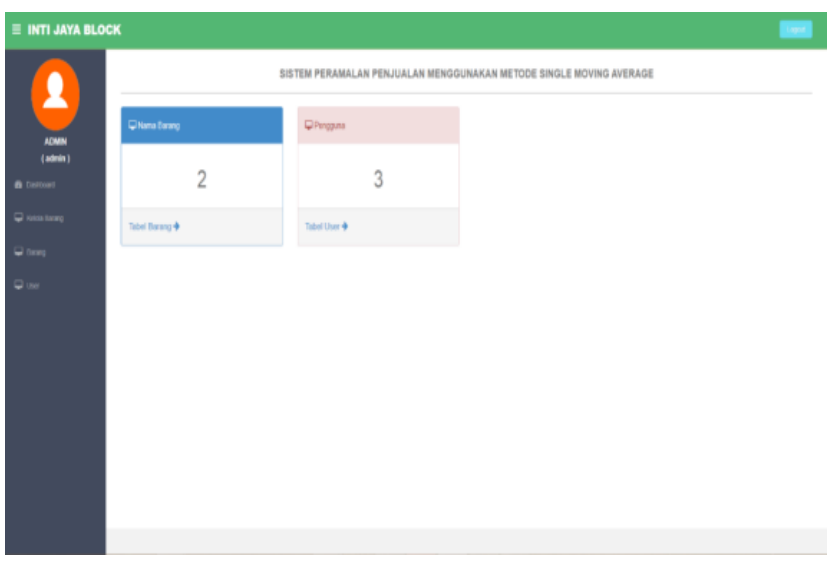

Gambar 4.3 Tampilan Halaman Utama

\section{Tampilan Transasik Penjualan}

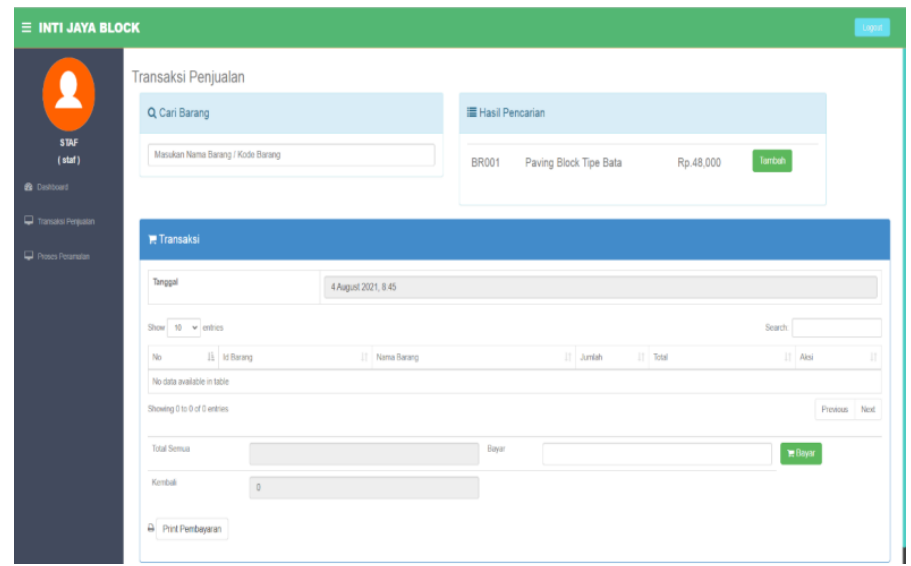

\section{Gambar 4.4 Tampilan Transaksi Penjualan}

\section{Tampilan Proses Perhitungan Peramalan}

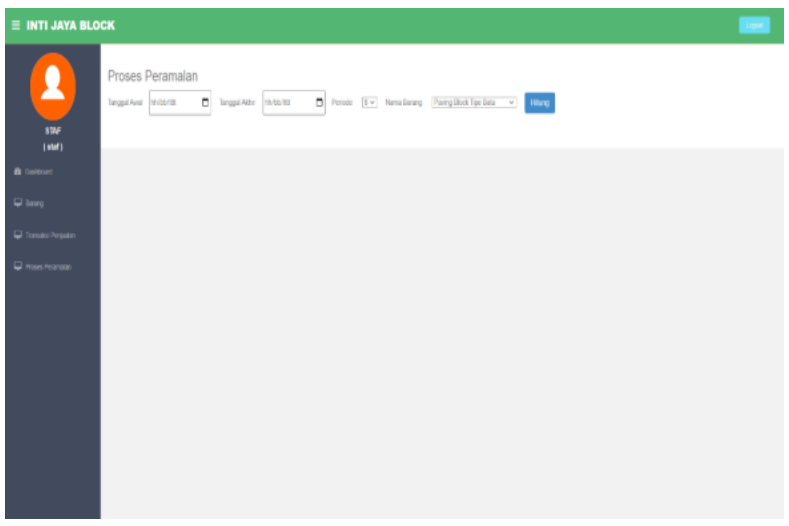

Gambar 4.5 Tampilan Proses PerhitunganPeramalan

\section{Tampilan Hasil Peramalan}

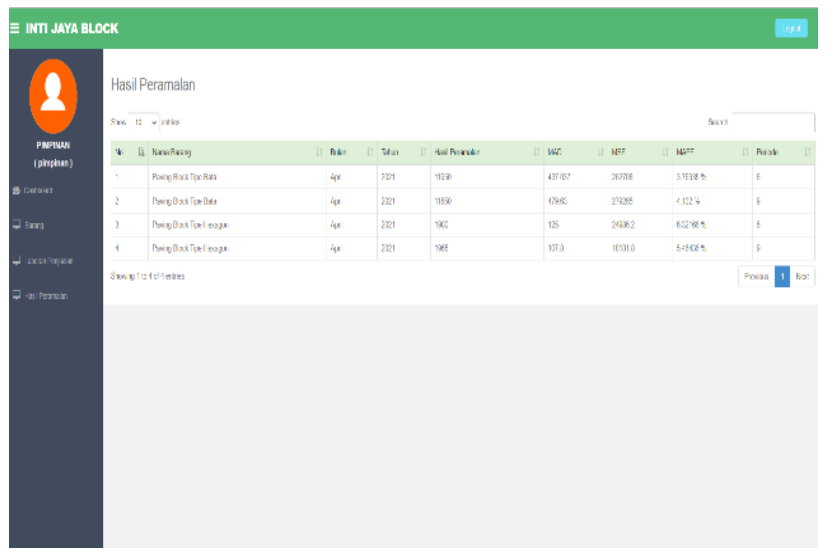

Gambar 4.6 Halaman Hasil Peramalan

\section{KESIMPULAN}

Sistem peramalan penjualan kavling block dengan menggunakan metode Single Moving Averaged dibuat untuk membantu pihak perusahaan dalam menentukan jumlah produksi pada periode berikutnya.

Hasil perhitungan peramalan penjualan kavling block metode singel moving average diuji tingkat akurasinya dengan menggunakan MAD, MSE dan MAPE. Dari hasil pengujian diperoleh nilai yang siginifikan dan dapat dijadikan acuan untuk menentukan jumlah produksi untuk periode berikutnya.

\section{UCAPAN TERIMA KASIH}

Terima kasih kami ucapkan semua pihak yang telah memberikan kesempatan kepada kami untuk melakukan 
riset, dan juga kepada stakeholder tidak dapat kami sebutkan satu persatu sehingga tulisan ini dapat diselesaikan.

\section{REFERENSI}

[1]. Anggraeni, E. Y., \& Irviani, R.. Pengantar Sistem Informasi. Yogyakarta: Andi. ISBN: 978-979-296-277-2. 2017.

[2]. H. R. Naufal and R Adrean, "R. naufal Hayâ and R. Adrean, 'Sistem Informasi Inventory Berdasarkan Prediksi Data Penjualan Barang Menggunakan Metode Single Moving Average Pada CV. Agung Youanda,' ProTekInfo (Pengembangan Ris. dan Obs. Tek. Inform., vol. 4, pp. 29-33, 2017," ProTekInfo (Pengembangan Ris. dan Obs. Tek. Inf., vol. 4, pp. 29-33, 2017. [4] G. Vincent, Total Quality Cont

[3]. Herlawati \& Widodo. Menggunakan UML.Informatika. Bandung.2011.

[4]. Kadir , A. Mudah Mempelajari Database Mysql. Yogyakarta: ANDI OFFSET.2010.

[5]. Muhajirin \& Maya, P. Pendekatan praktis metode penelitian kualitatif dan kuantitatif. Yogjakarta. Idea Press. ISBN:978-602-6335-35-7.2017

[6]. Nurlifa, A., \& Kusumadewi, S. Sistem Peramalan Jumlah Penjualan Menggunakan Metode Moving Average Pada Rumah Jilbab Zaky. INOVTEK Polbeng - Seri Informatika, 2(1), 18-25.2017.

[7]. Sukamto, R. A., \& Shalahuddin, M. Rekayasa Perangkat Lunak Terstruktur dan Berorientasi Objek. Bandung: Informatika. ISBN: 978-602-1514-05-4. 2016.

[8]. Sumari, A. D. W., Musthafa, M. B., Ngatmari, \& Putra, D. R. H. Perbandingan Kinerja Metode-Metode Prediksi pada Transaksi Dompet Digital di Masa Pandemi. JURNAL RESTI (Rekayasa Sistem dan Teknologi Informasi), 4(4), 642-647. 2020.

[9]. Yudaruddin, R. Forecasting: untuk Kegiatan Ekonomi dan Bisnis. Samarinda: RV Pustaka Horizon. ISBN: 978-6025431-48-7. 2019.

[10]. Yuniastari, N. A., \& Wirawan, I. W. (2014). "Peramalan Permintaan Produk Perak Menggunakan Metode Simple Moving Average Dan Exponential smoothing". Jurnal Sistem dan Informatika , 97-106. 